\title{
PEMBELAJARAN TEMATIK MENGGUNAKAN MEDIA VIDEO SCRIBE PADA SISWA KELAS IV SEKOLAH DASAR
}

\author{
Siti Badariah, Ricka Tesi Muskania, Mansur \\ email korespondensi: ricka.muskania@gmail.com \\ Jurusan Pendidikan Guru Madrasah Ibtidaiyah Fakultas Tarbiyah dan Ilmu Keguruan \\ Institut Agama Islam Negeri Pontianak
}

\begin{abstract}
Abstrak
Penelitian ini dilatar belakangi untuk meningkatakan hasil belajar siswa yang masih di bawah KKM 70,00 dengan menggunakan media video scribe. Penelitian ini bertujuan untuk mengetahui (1) Bagaimana hasil belajar siswa sebelum penggunaan media video scribe dalam pembelajaran tematik untuk meningkatkan hasil belajar siswa (2) Bagaimana hasil belajar siswa setelah penggunaan media video scribe dalam pembelajaran tematik untuk meningkatkan hasil belajar siswa (3) Apakah terdapat peningkatan hasil belajar siswa pada pembelajaran tematik setelah penggunaan video scribe sebagai media pembelajaran. Metode yang digunakan dalam penelitian ini adalah Penelitian Tindakan Kelas. Adapun bentuk penelitian ini menggunakan pendekatan kuantitatif dan kualitatif. Sumber data dalam penelitian ini adalah: Guru kelas IV Naim. Pelaksanaan pengumpulan data dalam teknik dokumentasi, pengukuran dan observasi. Hasil penelitian ini dapat menyimpulkan: 1). Hasil belajar siswa sebelum penggunaan media video scribe dalam pembelajaran tematik untuk meningkatkan hasil belajar siswa di kelas IV SD Islam Al-Azhar 21 Pontianak Tahun Pelajaran 2017/2018 hanya memperoleh 65,45 belum memenuhi KKM yaitu 07,00. Perolehan hasil tersebut dikarenakan guru tidak menggunakan media pembelajaran yang dapat membuat siswa semakin bersemangat dalam belajar dan lebih ceria. 2). Hasil belajar siswa setelah penggunaan media video scribe dalam pembelajaran tematik untuk meningkatkan hasil belajar siswa di kelas IV SD Islam Al-Azhar 21 Pontianak Tahun
\end{abstract}


Pelajaran 2017/2018 pada siklus I memperoleh nilai 79,09 dan pada siklus II memperoleh nilai 94,54 dan 3). Terdapat peningkatan hasil belajar siswa pada pembelajaran tematik setelah pengguaan video scribe sebagai media pembelajaran di kelas IV SD Islam Al-Azhar 21 Pontianak Tahun Pelajaran 2017/2018 terdapat peningkatan hasil belajar dari siklus I hingga siklus II sebesar 15,45.

Kata Kunci: Video Scribe, Pembelajaran Tematik, Hasil Belajar.

\section{Pendahuluan}

Guru, di dalam tugas profesinya, telah dibekali ilmu pengetahuan tentang berbagai cara yang harus ditempuhnya dalam upayah meningkatkan kemampuan siswanya. Diantaranya adalah pengetahuan tentang berbagai media pembelajaran, idealnya dengan bekal pengetahuan yang dimiliki guru harus mampu mengelolah proses pembelajaran dari materi pembelajaran yang disampaikannya. Sehingga output optimal yang diharapkan dari proses pembelajaran tersebut dapat tercapai.

Khususnya di dalam proses pembelajaran tematik di Sekolah Dasar, diharapkan Guru mampu mengelolah proses pembelajaran dengan media pembelajaran sedemikian rupa dengan memanfaatkan sarana dan prasarana yang tersedia. Sehingga output yang optimal dari proses pembelajaran tersebut dapat terwujudkan.

Sejalan dengan itu, media pembelajaran sama halnya dengan media pendidikan yang merupakan sebagai alat bantu komunikasi. Menurut Hamaliki (1986: 19) “Penggunaan media pembelajaran dalam proses pembelajaran dapat membangkitkan motivasi dan rangsangan kegiatan belajar." Penggunaan media pembelajaran pada tahap orientasi pembelajaran akan membantu keefektifan proses pembelajaran yang menyampaikan pesan dan isi pembelajaran saat itu. Selain membangkitkan motivasi dan minat siswa, media pembelajaran juga dapat membantu siswa meningkatkan pemahaman yang akan berpengaruh dengan hasil belajar siswa. 
Berdasarkan obsevasi awal pada kelas IV Naim setelah peneliti diberikan kesempatan untuk menggatikan guru kelas IV Naim. kesempatan ini Peneliti gunakan untuk melihat secara langsung kondisi kelas. Peneliti menumukan masalah yaitu kondisi kelas yang terjadi pada proses pembelajaran tidak kondusif. Hal ini dapat dilihat selama proses pembelajaran di kelas, siswa ribut, berbicara dengan teman sebangku, ada juga bermain saat proses pembelajaran berlangsung. Sementara usaha peneliti untuk menenangkan kondisi kelas, hanya sebentar didengarkan kemudian siswa kembali ribut. Peneliti berinisiatif menayangkan video Scribe yang sudah peneliti siapkan, hasilnya kondisi kelas yang awalnya ribut menjadi lebih kondusif, video Scribe yang ditampilkan menyita perhatian peserta didik. Untuk itulah peneliti berkeinginan melakukan penelitian tentang media video Scribe digunakan sebagai media pembelajaran.

Kesempatan kedua peneliti diajak guru kelas IV Naim untukmelihatproses pembelajaranyangdipimpinolehgurukelas secara langsung. Pada proses pembelajaran di kelas penggunaan media pembelajaran sangat minim dipergunakan guru. Buku paket dan papan tulis merupakan media unggulan yang ada di kelas. Penguasaan guru terhadap media pembelajaran berbasis teknologi sangat kurang padahal menurut Bambang Warsita (2008: 1) teknologi pembelajaran berupaya untuk memacu (merangsang) dan memicu (menumbuhkan) belajar, sehingga dapat meningkatkan proses pembelajaran yang berkualitas. Guru harus maksimal mempersiapkan dan berinovasi media pembelajaran agar proses pembelajaran semakin berkesan dan menyenangkan.

Adapun hasil prapenelitian yang peneliti lakukan pada siswa kelas IV Naim SD Islam Al-Azhar 21 Pontianak Tahun Pelajaran 2016/2017 semester satu pada pembelajaran tematik. Berdasarkan data hasil nilai ulangan harian tema 3 semester satu Tahun Ajaran 2016/2017, dari 22 siswa yang terdiri dari 13 perempuan dan 9 laki-laki, hanya 10 siswa yang sudah mencapai KKM yaitu 07,00 dengan rata-rata nilai 67,00 . 
Usai dilakukan prapenelitian di kelas IV Naim SD Islam Al-Azhar 21 Pontianak peneliti melihat penyebab masalah di atas adalah:

a. Siswajarang memperhatikan penjelasan guru karenakeadaan situas belajar membosankan, itu disebabkan minimnya media pembelajaran yang guru gunakan untuk membantu penyampaian materi.

b. Guru memiliki keterbatasan penguasaan berbagai media pembelajaran berbasis teknologi yang tepat untuk mengalihkan aktivitas dan kreativitas belajar siswa.

c. Hasil belajar siswa yang masih banyak di bawah standar KKM yaitu 70,00.

Berdasarkan permasalahan di atas, peneliti berkeyakinan bahwa untuk memecahkan permasalahan yang perlu dilaksanakan penelitian tindakan kelas dengan tujuan untuk memperbaiki proses pembelajaran yang ada sekaligus mengupayakan peningkatan hasil belajar siswa lebih maksimal. Agar penelitian ini dapat terlaksanakan, maka peneliti memfokuskan penelitian ini pada kelas IV Naim SD Islam Al-Azhar 21 Pontianak karena guru kelas kurang menguasai media pembelajaran berbasis teknologi dan prapenelitian juga dilakukan di kelas ini.

Memilih SD Islam Al-Azhar sebagai tempat meneliti karena sekolah ini berlokasi di tengah kota, sarana dan prasarana memadai dan sekolah ini merupakan sekolah favorite yang ada di kota Pontianak. Kemudian, peneliti memilih pembelajaran tematik yang akan dijadikan objek penelitian karena SD Islam Al-Azhar menggunakan kurikulum 2013.

Selanjutnya peneliti mencari dan memilih media untuk pembelajaran tematik di kelas IV Naim SD Islam Al-Azhar 21 Pontianak berbasis teknologi. Berdasarkan hasil seleksi, pilihan jatuh pada media pembelajaran video Scribe. Karena sarana dan prasarana memadai untuk menggunakan media video Scribe dan video scribe merupakan media audio visual yang memiliki tampilan suara dan gambar dapat melatih indera penglihatan dan pendengaran. Pengunaan video scribe juga membantu 
mempercepat pemahaman siswa dalam memahami materi yang disampaikan.

\section{Media Pembelajaran}

Azhar Arsyad (2014: 3) kata media berasal dari bahasa latin medium secara harfiah bearti tengah, perantaraan atau pengantar. Menurut Jamil Suprihatiningrum (2017: 319) media diartikan sebagai pengantar pesan dari pengirim kepada penerima. Garlach \& Eli menyatakan bahwa media secara garis besar adalah manusia, materi, atau kejadian yang mempengaruhi kondisi yang membuat siswa mampu memperoleh pengetahuan, keterampilan, atau sikap. Dalam pengertian ini, guru, buku, dan lingkungan sekolah merupakan media.

Media Video Scribe

Video Scribe tergolong media berunsur audio visual, yaitu penggambungan media audio dan media visual. Media audio adalah media yang hanya dapat didengar dengan menggunakan indera pendengaran saja. Sedangkan media visual adalah media yang hanya dapat dilihat dengan menggunakan beberapa media gambar mati atau bergerak. (Rusman dkk 2015: 182-183)

Video scribe media pembelajran berbasis teknologi dan terdapat banyak aplikasi keren dan unik, sehingga cocok digunakan sebagai media pembelajaran agar peserta didik lebih suka dan terhibur dengan tampilan yang menarik sehingga proses pembelajaran lebih ceria dan menyenangkan.

\section{Langkah-Langkah Pelaksanaan Pembelajaran Media Video Scribe}

a. Peserta didik secara serempak menjawab salam yang diucapkan guru dan berdoa bersama dipimpin oleh salah seorang peserta didik dengan penuh khidmat;

b. Presensi

c. Guru melakukan Appersepsi

d. Guru menyampaikan tujuan pembelajaran yang ingin dicapai 
e. Guru menyampaikan gambaran pelaksanaan pembelajaran dengan media video scribe

f. Motivasi awal guru menayangkan (Video)

\section{Mengamati}

a. Peserta didik mencermati tayangan video scribe terkait dengan materi daur hidup hewan

\section{Mengkomunikasikan}

a. Peserta didik diminta untuk memberikan tanggapan tentang tanyangan video yang telah dicermati melalui video scribe

b. Peserta didik menyimak penjelasan guru tekait materi daur hidup hewan

\section{Menanyakan}

a. Peserta didik diberi kesempatan untuk bertanya berkaitan dengan materi daur hidup hewan

b. Guru memberikan penjelasan berkaitan dengan apa yang ditanyakan siswa

\section{Mencipta}

a. Peserta didik menciptakan produk dari proses pembelajaran

\section{Mencoba}

a. Peserta didik mempersentasikan hasil produk yang telah diciptakan

\section{Menalar}

a. Menemukan kata-kata sulit dari puisi teman

b. Peserta didik menyanyikan lagu

c. Guru mengajak peserta didik menyimpulkan materi pembelajaran

d. Guru melaksanakan penilaian

e. Feed Back terhadap hasil Evaluasi

f. Guru memfollow up hasil Feed Back dari evaluasi

g. Motivasi akhir guru menyangkan video terkait yang hewan

h. Bersama membaca doa penutup dan diakhiri dengan salam 


\section{Keunggulan Media Video Scribe}

a. Tampilan lebih menarik.

b. Dapat dibuat sesuai keinginan.

c. Waktu penayangan bisa diatur sesuai kebutuhan.

d. Tidak memakan biaya.

e. Bisa digunakan untuk semua jenis materi.

f. Pengerjaannya bisa online atau offline.

\section{Kekurangan Media Video Scribe}

a. Cara penginstal aplikasi video scribe cukup rumit bagi pemula.

b. Sarana dan prasarana harus memadai.

c. Jika masih dalam bentuk file mentah dan belum disimpan dalam bentuk file video maka pemutaran video scribe hanya bisa dilaptop yang digunakan untuk membuat video scribe tersebut.

\section{Pembelajaran Tematik}

Pembelajaran tematik adalah program pembelajaran yang berangkat dari satu tema atau topik tertentu dan kemudian dielaborasi dari berbagai aspek atau tinjauan dari persepktif mata pelajaran yang biasa diajarkan di sekolah. Pembelajaran tematik yang disebut dengan pembelajaran terpadu sebagai terjemahan dari integratif teaching dan learning. Bahkan disebut juga pendekatan kurikulum terpadu. Pembelajaran tematik terpadu atau tematik menawarkan model-model pembelajaran yang menjadi aktifvitas pembelajaran itu relevan dan penuh makna bagi siswa, baik formal maupun informal, meliputi pembelajaran inquiry secara aktif sampai dengan penyerapan pengetahuan dan fakta secara pasif, dengan memberdayakan pengetahuan dan pengalaman siswa untuk membantunya mengarti dan memahami dunia kehidupan. (Kadir \& Hanun 2014)

\section{Hasil Belajar}

Menurut Nana Sudjana (Dalam Salama, 3013: 17) menyatakanbahwa, "Hasilbelajarmerupakan perubahantingkah 
laku yang mencakup bidang kognitif, efektif dan psikomotorik". Sedangkan Suprijono (dalam M.Thobrani \& Arief, 2013: 22) hasil belajar adalah pola-pola perbuatan, nilai-nilai, pengertianpengertian, sikap-sikap, apresiasi, dan keterampilan.

Berdasarkan paparan di atas, menurut Suprijono (dalam Thobroni, 2015: 20) Merujuk pemikiran Gegne, hasil belajar berupa hal-hal berikut:

a. Informasi verbal, yaitu kapabilitas menggungkapkan pegetahuan dalam bentuk bahasa, baik lisan maupun tertulis, kemampuan merespons secara spesifik terhadap rangsangan spesifik. Kemampuan tersebut tidak memerlukan manipulasi simbol, pemecahan masalah, maupun penerapan.

b. Keterampilan intelektual, yaitu kemampuan mempresentasikan konsep dan lambang. Keterampilan intelektual terdiri dari kemampuan mengategorisasi, kemampuan analisis-sintesis fakta-konsep, dan mengembangkan prinsip-prinsip keilmuan. Keterampilan intelektual merupakan kemampuan melakukan aktivitas kognitif bersifat khas.

c. Strategi kognitif, yaitu kecakapan menyalurkan dan mengarahkan aktivitas kognitifnya. Kemampuan ini meliputi penggunaan konsep dan kaidah dalam memecahkan masalah.

d. Keterampilan Motorik, yaitu kemampuan melakukan serangkaian gerak jasmani dalam urusan dan koordinasi, sehingga terwujud otomatisme gerak jasmani.

e. Sikap adalah kemampuan menerima atau menolak objek berdasarkan penilaian terhadap objek tersebut. Sikap berupa kemampuan menginternalisasi dan eksternalisasi nilainilai. Sikap merupakan kemampuan menjadikan nilai-nilai sebagai standar perilaku.

Berdasarkan pendapat di atas, bahwa hasil belajar pada pembelajaran tematik merupakan hasil dari berakhirnya proses pembelajaran yang dilakukan oleh guru selama proses pembelajaran di kelas. Evaluasi dilakukan untuk mengetahui sejauhmana penguasaan dan pemahaman siswa tentang materi yang telah disampaikan, baik berupa tes lisan atau tes tertulis. 


\section{Penyebab Perbedaan Hasil Belajar Siswa}

Dalam kegiatan-kegiatan proses belajar mengajar, seorang guru perlu mempertimbangkan faktor-faktor peserta didik sebagai penerima pelajaran. Jadi keberhasilan proses belajar mengajar ditentukan oleh kesiapan siswa untuk menerima pelajaran maka untuk mencapai keberhasilan siswa dalam belajar seorang guru harus mampu memperhatikan dan mengetahui tentang sikap dan perilaku tiap peserta didik serta faktor-faktor yang mempengaruhi hasil belajarnya.

Dalyono (2010: 55) berhasil atau tidaknya seseorang dalam belajar disebabkan beberapa faktor yang mempengaruhi pencapaian hasil belajar yaitu berasal dari dalam dan luar dirinya.

\section{Metode Penelitian}

Jenis Penelitian ini menggunakan pendekatan kuantitatif dan kualitatif dalam bentuk Penelitian Tindakan Kelas (Classroom Action Research), yang berarti penelitian yang dilakukan pada sebuah kelas untuk mengetahui akibat tindakan yang diterapkan pada suatu subjek penelitian di kelas tersebut. Menurut Fahrul Razi (2011: 12) penelitian tindakan kelas pertama kali dikenalkan oleh Kurt Lewin pada tahun 1946, yang selanjutnya dikembangkan oleh Stephen Kmmis, Robin Mc Tanggart, John Elliot, Deva Ebbutt dan lainnya.

\section{Hasil Penelitian}

Berdasarkan data yang sudah terkumpul hasil belajar siswa sebelum penggunaan media video scribe dalam pembelajaran tematik untuk meningkatkan hasil belajar siswa di kelas IV SD Islam Al-Azhar 21 Pontianak Tahun Pelajaran 2017/2018 terdapat 12 orang yang belum tuntas dengan rata-rata nilai yaitu 65,45 dan masih di bawah KKM 07,00. Perolehan hasil tersebut dikarenakan guru tidak menggunakan media pembelajaran yang dapat membuat siswa semakin bersemangat dalam belajar dan lebih ceria. 
Pada prasiklus sebanyak 12 dari 22 orang siswa yang belum tuntas atau belum mencapai KKM 07,00. 12 orang siswa terdapat satu orang siswa tidak hadir dikarenakan sakit. 12 orang yang belum tuntas dengan persentase nilai $54,54 \%$ pada prasiklus. Kemudian pada siklus I sebanyak 6 orang siswa yang belum tuntas dengan persentase nilai $27,27 \%$. Sedangkan pada siklus II siswa yang belum tuntas menurun menjadi 4,54\%. Siklus II hanya 1 dari 22 orang siswa yang belum tuntas dengan persentase nilai yang belum tuntas yaitu 4,54\%. Sedangkan persentase siswa yang sudah tuntas meningkat dari prasiklus $45,45 \%$ meningkat menjadi $72,72 \%$ pada siklus I kemudian pada siklus ke II meningkat menjadi 95,45\%.

\section{Simpulan}

Berdasarkan hasil penelitian yang diperoleh melalui penelitian penggunaan media video scribe dalam pembelajaran tematik untuk meningkatkan hasil belajar siswa di kelas IV SD Islam Al-Azhar 21 Pontianak Tahun Pelajaran 2017/2018 dapat disimpulkan Hasil belajar siswa sebelum penggunaan media video scribe dalam pembelajaran tematik untuk meningkatkan hasil belajar siswa di kelas IV SD Islam Al-Azhar 21 Pontianak Tahun Pelajaran 2017/2018 terdapat 12 orang yang belum tuntas dengan rata-rata nilai yaitu 65,45 dan masih di bawah KKM 07,00. Perolehan hasil tersebut dikarenakan guru tidak menggunakan media pembelajaran yang dapat membuat siswa semakin bersemangat dalam belajar dan lebih ceria. Hasil belajar siswa setelah penggunaan media video scribe dalam pembelajaran tematik untuk meningkatkan hasil belajar siswa di kelas IV SD Islam Al-Azhar 21 Pontianak Tahun Pelajaran 2017/2018 pada siklus I memperoleh nilai 79,09 dan ada 6 orang siswa yang belum tuntas, kemudian pada siklus II rata-rata nilai siswa meningkat menjadi 94,54 dan hanya satu orang siswa yang belum tuntas itu pun siswa tersebut tidak masuk sekolah karena sakit. 


\section{Daftar Pustaka}

Azhar Arsyad. 2014. Media Pembelajaran. Jakarta:PT Rajagrafindo Persada.

Bambang Warsita. 2008. Teknologi Pembelajaran. Jakarta: Rineka Cipta.

Fahrul Razi. 2011. Panduan Penelitian Tindakan Kelas. Pontianak: Stain Press.

Jamil Suprihartiningrum. 2017. Strategi Pembelajaran. Yogyakarta: Ar-Ruzi Media.

J .Moleong Lexy. 2013. Metodologi Penelitian Kualitatif. Bandung: PT Remaja Rosdakarya.

Kadir dan Hanun. 2014. Pembelajaran Tematik. Jakarta: PT Rajagrafindo Persada.

M. Dalyono. 2010. Psikologi Pendidikan. Jakarta: PT Rineka Cipta.

M. Thobrani. 2015. Belajar Dan Pembelajaran. Yogyakarta: ArRuzz Media.

Rusman Dkk. 2012. Pembelajaran Berbasis Teknologi Informasi Dan Komunikasi Pengembangan Propesionalitas Guru. Jakarta: PT Rajagrafindo Persada.

Salama. 2013. Peningkatan Hasil Belajar Siswa Dengan Menggunakan Strategi Card Sort Pada Mata Pelajaran Fiqih Materi Makanan Dan Minuman Yang Halal Dan Haram Di Kelas V Madrasah Ibtidahiyah Swasta Al-Ihsan Kecamatan Pontianak Utara Tahun 2012/2013. 
86| Siti Badariah dkk

Elementary Vol. 7 No.1 Januari-Juni 2019 